\title{
Archaeological Survey of the Crystal City Municipal Landfill Extension, Zavala County, Texas
}

Richard A. Jones

Follow this and additional works at: https://scholarworks.sfasu.edu/ita

Part of the American Material Culture Commons, Archaeological Anthropology Commons, Environmental Studies Commons, Other American Studies Commons, Other Arts and Humanities Commons, Other History of Art, Architecture, and Archaeology Commons, and the United States History Commons

Tell us how this article helped you.

This Article is brought to you for free and open access by the Center for Regional Heritage Research at SFA ScholarWorks. It has been accepted for inclusion in Index of Texas Archaeology: Open Access Gray Literature from the Lone Star State by an authorized editor of SFA ScholarWorks. For more information, please contact cdsscholarworks@sfasu.edu. 


\section{Archaeological Survey of the Crystal City Municipal Landfill Extension, Zavala County, Texas}

\section{Creative Commons License}

\section{(c) (1) (8)}

This work is licensed under a Creative Commons Attribution-NonCommercial 4.0 International License 


\title{
Archaeological Survey of the Crystal City Municipal Landfill Extension, Zavala County, Texas
}

\author{
Richard A. Jones
}

Center for Archaeological Research The University of Texas at San Antonio Archaeological Survey Report, No. 305

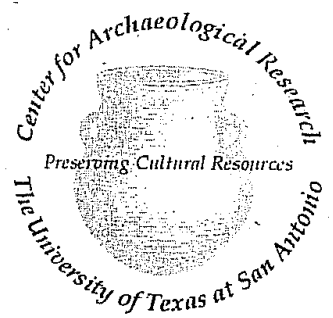


The following information is provided in accordance with the General Rules of Practice and Procedure, Chapter 41.11 (Investigative Reports), Texas Antiquities Committee:

1. Type of investigation: Intensive Survey

2. Project name: Crystal City Landfill Extension

3. County: Zavala

4. Principal investigator: Robert J. Hard

5. Name and location of sponsoring agency: Ozuna and Associates, Inc., 8118 Broadway, San Antonio, Texas 78209

6. Texas Antiquities Permit No.: 2298

7. Published by the Center for Archaeological Research, The University of Texas at San Antonio, 6900 N. Loop 1604 W., San Antonio, Texas 78249-0658, 2000

A list of publications offered by the Center for Archaeological Research is available. Call (210) 458-4378; or write to the Center for Archaeological Research, The University of Texas at San Antonio, 6900 N. Loop 1604 W., San Antonio, Texas 78249-0658; e-mail address is car@lonestar.utsa.edu; or visit CAR's web site at http://csbs3.utsa.edu/car. 


\begin{abstract}
At the request of Ozuna and Associates, Inc., Consulting Engineers of San Antonio, Texas, an archaeological survey was conducted by the Center for Archaeological Research (CAR) for a proposed 40-acre extension to the Crystal City Municipal Landfill, under Texas Antiquities Committee Archeology Permit Number 2298. The pedestrian survey was conducted in early January 2000. One prehistoric site (41ZV445), a sparse scatter of burned stone and chipped lithics, was identified and documented. Shovel testing revealed no subsurface cultural deposits. The site does not meet the criteria for potential eligibility to the National Register of Historic Places nor does it warrant State Archaeological Landmark designation. Cultural resource clearance is recommended for the proposed landfill extension.
\end{abstract}




\section{Contents}

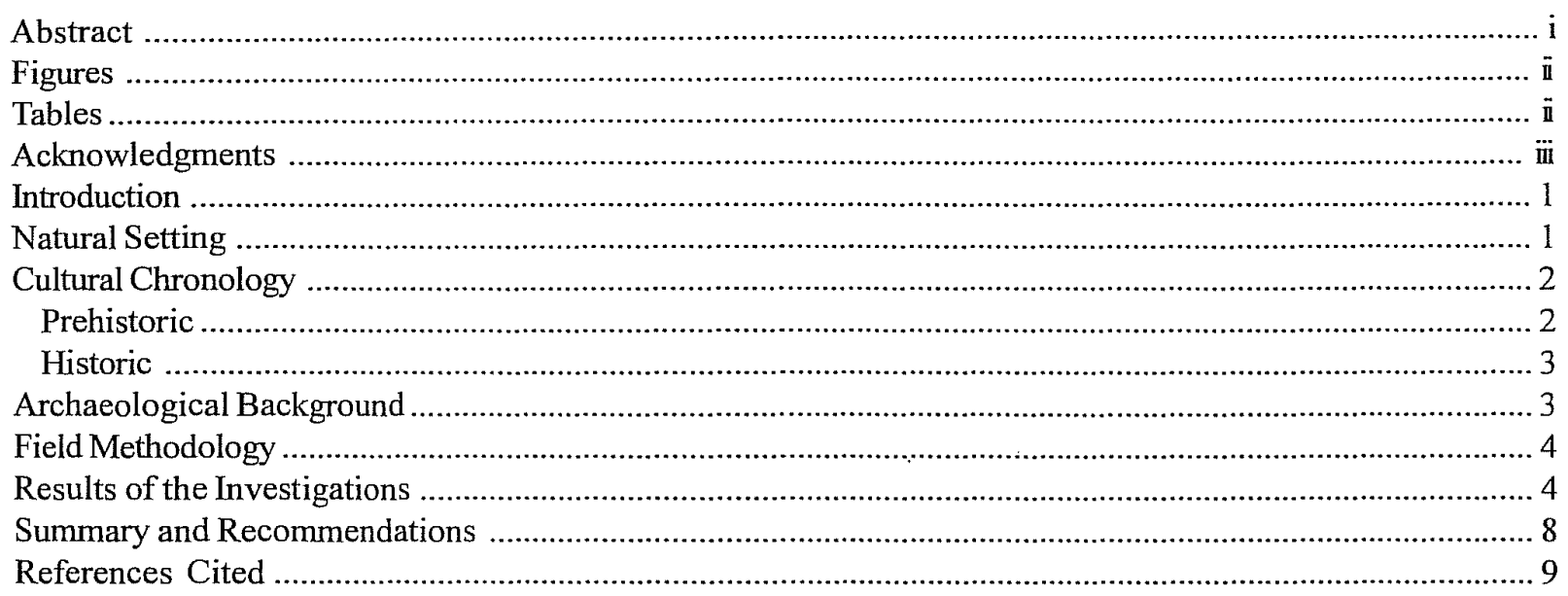

\section{Figures}

Figure 1. Location of Crystal City, Texas and project area. .................................................................. 1

Figure 2. Distribution of transects, shovel tests, and location of site 41ZV445 within the project area. ............ 5

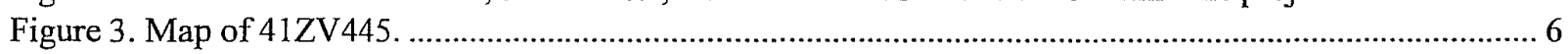

\section{Tables}

Table 1. Artifact Inventory and depth of shovel tests 


\section{Acknowledgments}

The author would like to thank Dr. Robert Hard (Director of the Center for Archaeological Research) who served as Principal Investigator, and Dr. Steve Tomka (Project Manager) for giving me their professional advice and guidance throughout the project. I am also indebted to them for giving me my first project archaeologist assignment. I would also like to thank Mr. George Ozuna, Jr., of Ozuna and Associates, Inc., and Mr. Ramon de la Fuente, City Manager, Crystal City, for their assistance in making this project possible. The project could not have been completed without the hard work and help of CAR staff archaeologist Rick Robinson. Ruth Mathews contributed her expertise in drafting. The technical support of editor Maryanne King is greatly appreciated. 


\section{Introduction}

On January 6-7,2000, personnel from the Center of Archaeological Research (CAR) at The University of Texas at San Antonio (UTSA) conducted an archaeological survey of 40 acres (403 meters $\times 402$ meters) located within the northwestern confines of the Crystal City Municipal Landfill. The landfill is located approximately 6 kilometers north-northwest of Crystal City, Texas (Figure 1). The goal of this survey was to identify and document any Historic or Prehistoric cultural resources that may be impacted by the proposed extension to the existing landfill.

\section{Natural Setting}

The Crystal City Municipal landfill project area is situated in an upland setting (620-640 feet above sea level) and is located in the western portion of the NuecesGuadalupe Plain biogeographical area of the South Texas Plains (Black 1989a:39). The NuecesGuadalupe Plain has a semi-arid sub-tropical climate featuring mild winters, an annual precipitation of 21.54 inches, and an average 272 day frost-free growing season (Black 1989b).

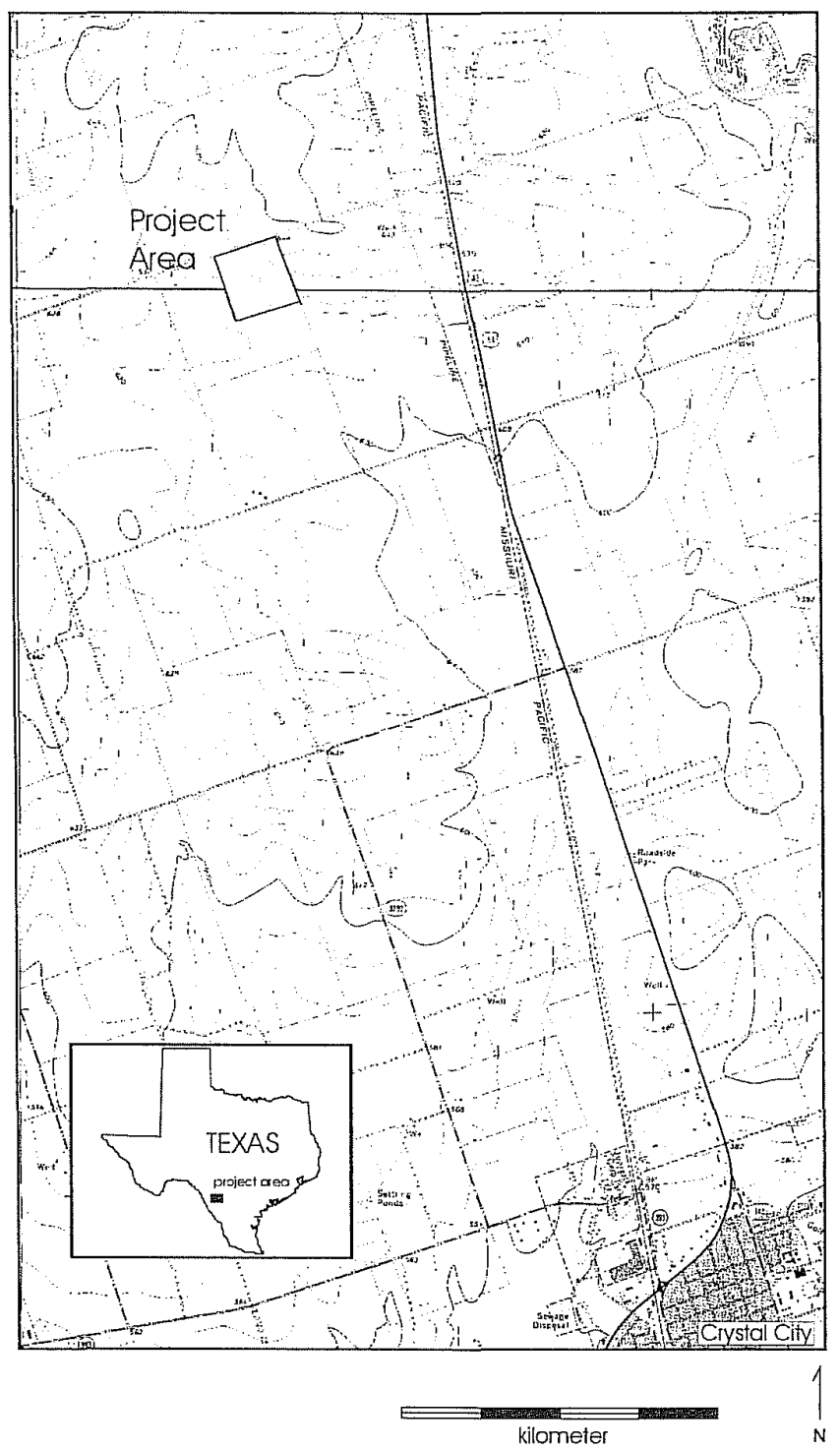

Figure 1. Location of Crystal City, Texas and project area. 
The project site is located on a north-south sloping colluvial surface (640-620 feet). Surface runoff flows into an unnamed ephemeral creek situated immediately south of the project area. This creek then empties into the Nueces River which is located approximately 4.5 kilometers east.

The vegetation in the vicinity of the project area consists of typical South Texas Brush Country species dominated by:

$$
\begin{aligned}
& \text { Mesquite (Prosopis juliflora), } \\
& \text { White brush (Aloysia texana), } \\
& \text { Prickly pear (Opuntia lindheimeri), and } \\
& \text { Grasses (buffalo, grama, and tobresa). }
\end{aligned}
$$

Cottontail rabbits (Sylvilagus Sp.) and whitetail deer (Odocoileus virginianus) comprise the fauna noted within the project area during the survey.

The project area falls within the Cotulla series clayloams (Stevens and Arriaga 1985: 51). While a 5-20 $\mathrm{cm}$ layer of colluvial sandy loam covers the surface, deeper deposits consist of relatively compact clay loam.

\section{Cultural Chronology}

This section provides a brief cultural and historical context for south Texas. For a more detailed discussion the reader is referred to Black (1995), Hester (1995), and Vierra (1998).

\section{Prehistoric}

\section{Paleoindian}

This period lasted from 11,200 to 7,950 B.P. in south Texas (Hester 1995:433-436). As is the case in Central Texas (Collins 1995), the Paleoindian period can be divided into early and late segments. Diagnostic artifacts of the early Paleoindian segment include Clovis and Folsom projectile points. Within Texas's political boundaries, Meltzer and Bever (1995:47-81) have documented the presence of 406 Clovis points in 128 of 254 counties. Other artifacts associated with the Clovis culture include bifaces, prismatic blade cores and blades, engraved stones, bone and ivory points, stone bolas, ochre, and shaft straighteners. Folsom points are also widely distributed throughout the Southern Plains and in Texas (Chandler and Kumpe 1994; Largent et al. 1991). Other elements of Folsom lithic technology include ultra-thin bifacial knives, spurred end scrapers, and gravers. Late Paleoindian projectile points include the Golandrian-Barber series and the St. Mary's Hall type (Collins and Kerr 1993).

\section{Archaic}

The Archaic period lasts from roughly $7950-1250$ в.P. Hester (1995) divides the south Texas Archaic into four sub-periods:

\section{Early Archaic; \\ Middle Archaic; \\ Late Archaic; and \\ Transitional Archaic.}

\section{The Early Archaic}

The Early Archaic ranges from roughly 7950 to 4450 B.P. (Hester 1995:436-438). Early Corner Notched and Early Basal Notched dart points are the two projectile point series commonly considered as representative of the period. Recently, the Angostura type has also been grouped with Early Archaic forms (Collins 1995). The extinction of large herds of mega-fauna and the changing climate at the beginning of the Holocene led to changes in land-use strategies by the hunter-gatherers of South Texas (McKinney 1981). Hunter-gatherer land-use strategies were based on high mobility and the exploitation of a wide range of resources such as prickly pear, rodents, rabbits, and deer (Story 1985:38-39, Weir 1976).

\section{The Middle Archaic}

The Middle Archaic ranges from 4450 to 2350 B.P. (Hester 1995:438-441). The amelioration of warm and dry conditions during the Altithermal may have led to increased population densities during the period (Sollberger and Hester 1972:338; Story 1985:40; Weir 1976:125, 128). On South Texas Plains, the exploitation of widely scattered, year-round resources such as prickly pear continued (Campbell and Campbell 1981:13-15), as did the hunting of deer, rabbits, and bison (Dillehay 1974). 


\section{The Late Archaic}

The Late Archaic extended from 2350 to 1250 B.P. (Hester 1995:441). Although inhabitants of the South Texas Plain near Brownsville and Rockport had begun to make pottery by about 1750 B.P., the northern part of the plain was still "preceramic" until 1,000 years later (Story 1985:45-47). Late Archaic points tend to be much smaller than Middle Archaic specimens. The most common types include Ensor, Ellis, Edgewood, Fairland, and Frio (Turner and Hester 1993:114,122).

\section{The Transitional Archaic}

The Transitional Archaic represents the last of the Archaic adaptations in Texas. Turner and Hester (1993:62-63) place the Transitional Archaic between 2250-1250 B.P., and Weir (1976) defines the Terminal Archaic, his version of the Transitional Archaic, as occurring between 1650 to 1150 в.P. Weir (1976) believes that this period represents the disappearance of burned rock middens and bison, and a reappearance of highly mobile hunters and gatherers. Others (Blāck and McGraw 1985; Peter 1982; Skelton 1977) argue that the use of burned rock middens did not cease in all regions of Texas.

\section{Late Prehistoric}

The date of 1200 B.P. marks the beginning of the Late Prehistoric in central Texas. A series of distinctive traits marks the shift from the Archaic to the Late Prehistoric lifeways, including the technological shift to the bow and arrow and the introduction of pottery to Central Texas and the northern South Texas Plain (Black 1989c:32; Story 1985:45-47). The Late Prehistoric period has been divided into two phases.

\section{The Austin Phase}

The Austin Phase was a time of population decrease (Black 1989c:32). Even though small burned rock middens associated with Edwards and Scallorn points have been found (Goode 1991:71; Houk and Lohse 1993:193-248), they are rare.

\section{The Toyah Phase}

The Toyah phase, beginning around 650 B.P., is characterized by the introduction of bladelet technology, the appearance of the first ceramics in Central Texas (bone-tempered plainware), and the use of a lithic tech- nology consisting of Perdiz arrow points, alternately beveled knives, and tear-shaped end scrapers (Black 1989c:32; Huebner 1991:346). Prewitt (1985) and Black (1989c) suggest that this technology encroached from north-central Texas. Hester (1995:444) recognizes this phase as the "best documented Late Prehistoric pattern" throughout south Texas, with dates ranging between ca. $650 / 700$ to $300 / 350$ в.P.

\section{Historic}

Collins (1995:386-387) identifies the Historic period as ca. 260 B.P. in central Texas. Hester (1995:450451) suggests that indigenous groups may have been affected by European influence even prior to the appearance of the first written records. He proposes that this period be more appropriately labeled as the "Protohistoric." A wealth of information is emerging on the lifeways of indigenous groups inhabiting and exploiting different portions of Texas during the seventeenth and eighteenth centuries (Campbell and Campbell 1981, 1988; Foster 1995). Used with care (McGraw and Corbin 1999), these and other sources can provide excellent sources of analogies and models for prehistoric adaptations throughout Texas.

\section{Archaeological Background}

Numerous archeological surveys and excavations have taken place in Zavala County. Regional surveys under the direction of T. R. Hester in the $1970 \mathrm{~s}$ on Chaparossa Ranch (located in northwestern Zavala County approximately $15 \mathrm{~km}$ Nw of the current project area) documented numerous open campsites, lithic procurement areas, and temporary campsites (Black 1989c:44-46; Hester 1995:430). Similar site types were observed on excavations done on Tortugas Ranch and Nelson farm (41ZV1-8), located approximately 18$\mathrm{km}$ east of the current project area. The Sonny Harkey site (41ZV137), located 5-km SSE of Crystal City, is perhaps the closest archaeological site to the project area. The site was described as a $457 \times 183$ meter occupation area that was comprised of numerous surface scatters of artifacts (hearth stones, flakes, bifaces). The site has been heavily collected since the 1930s (Site Survey Form on file at the Texas Archeological Research Laboratory, The University of Texas at Austin). 


\section{Field Methodology}

The 40-acre pedestrian survey of the proposed landfill extension was carried out using 20 meter transect intervals. A total of 21 transects were traversed in surveying the project area. In conjunction with the pedestrian survey, a total of 21 shovel tests were excavated (Figure 2). Of these, 20 (STs 1-20) were systematically spaced on a 90 -meter grid. ST 21 was excavated in the vicinity of ST 18 , within a sparse scatter of burned rock and lithic debitage (41ZV445)

The STs were excavated in $10 \mathrm{~cm}$ levels to a depth of $60-\mathrm{cm}$ bs. All matrix was screened through $1 / 4$-inch hardware cloth. All artifacts recovered from shovel testing were returned to CAR for laboratory processing and curation. No surface artifacts were noted. It was felt that the moderate surface visibility throughout much of the area, in conjunction with the inspection of recently disturbed soils and animal burrows in the lower visibility areas, offered a good strategy to ensure that surface cultural materials would be noted when present.

\section{Results of the Investigations}

The eastern two-thirds of the project area had been heavily disturbed by brush clearing operations that left deep tire tracks, large soil piles, and furrows throughout the area. The construction of an 8-10 meter wide gravel road that parallels the eastern boundary of the 40-acre tract also resulted in subsurface disturbances along the eastern edge of the property (Figure 2). A small (3.5 meter), recently constructed, square structure is present in the northeast corner of the property adjacent the gravel road. Its construction has also contributed additional subsurface disturbances. A moderate to thin carpet of grasses covers the eastern two-thirds of the property. Surface visibility ranges from moderate to relatively low. Throughout the project area, and in particular in the lower surface visibility sections, all furrows and soil piles were carefully inspected for evidence of cultural materials.

The brush clearing operations, as well as the road and building construction, did not appear to have occurred immediately prior to the survey conducted by CAR.
Based on vegetation regrowth, and erosion of the dirt road, these construction and clearing activities may have occurred within the past one to three years.

The western one-third of the tract is covered by a thin carpet of short grasses, and intermittent brush and mesquite trees. Numerous mesquite trees, up to three meters in height with diameters of 20-35 centimeters, were observed within this portion of the project area. Surface visibility here ranged from moderate to high. Back dirt from all animal burrows was carefully inspected for indications of cultural materials.

The $100 \%$ pedestrian survey of the proposed 40 -acre Crystal City Landfill Extension resulted in the identification and documentation of one site (41ZV445). In addition, three isolated STs (STs: 1, 3, and 5) contained modern cultural material or material of questionable origin.

\section{$41 Z V 445$}

This site is located in the west-central portion of the project area (Figure 2) and consists of a $20 \times 25$ meter sparse burned rock and lithic debitage scatter (see Figure 3). Six pieces of fine-grained quartzite debitage were encountered on the west-central portion of the site. They consist of primary and secondary flakes and represent core preparation and the early stages of core reduction for flake blank production. A light scatter of fire-cracked quartzite (e.g., extremely sharp, angular edges and convex exfoliated surfaces) is present across the site forming no particular concentrations. Two shovel tests (STs 18,21) were placed within the site boundaries to ascertain the presence and extent of buried cultural deposits. With the exception of burned rock (quartzite) observed on the surface of ST $2 I(n=5)$, the two shovel tests revealed no buried cultural deposits.

Judging from its size and artifact content, the site may represent the remains of a temporary campsite or lithic procurement locality. The absence of in situ hearth features, the apparent disturbed nature of the former hearths, and the low density of artifacts seriously limits the research potential of the site. 
This page has been

redacted because it

contains restricted

information. 


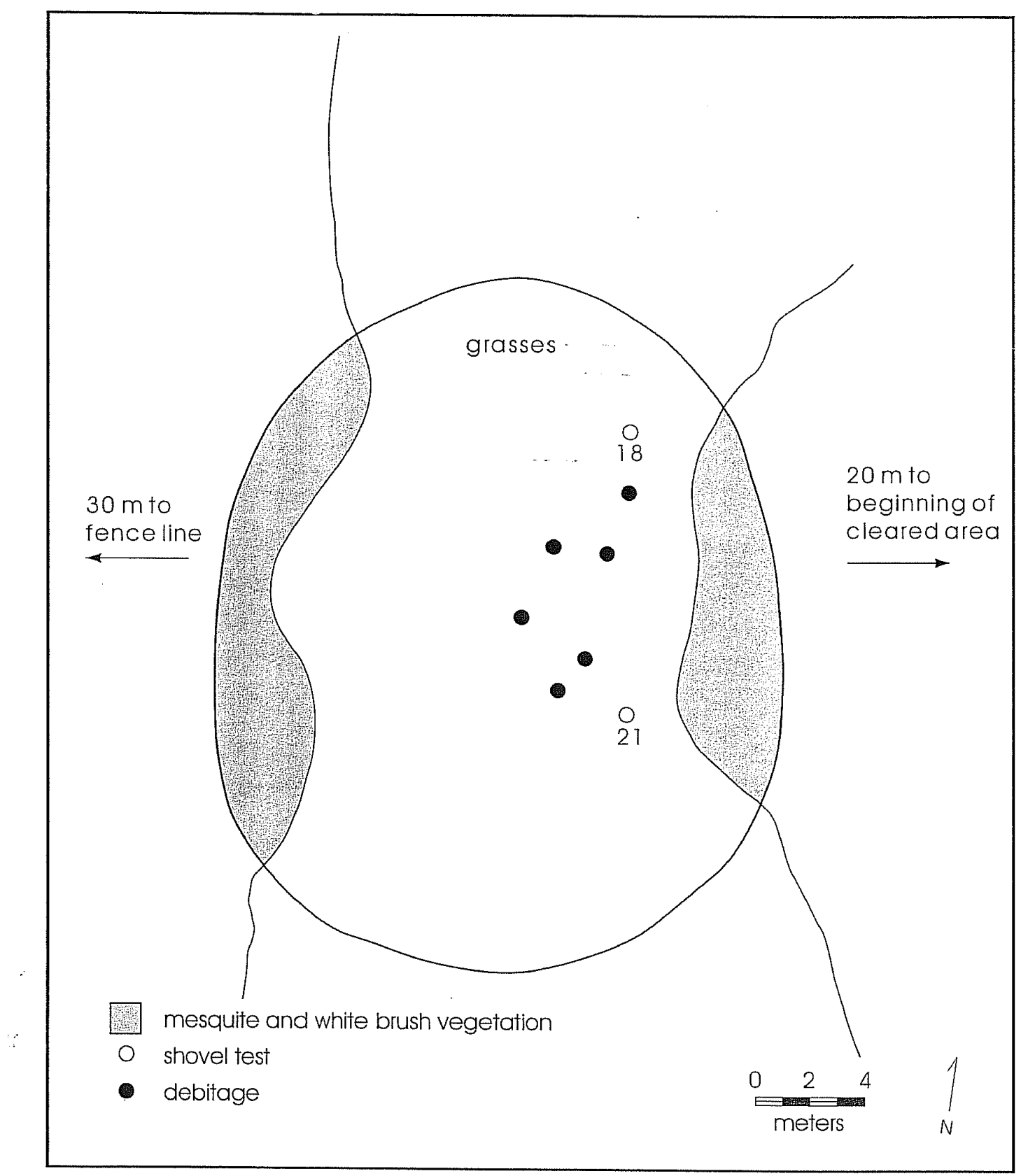

Figure 3. Map of $41 Z V 445$. 
Only three of the 21 shovel tests dug in the 40-acre project area yielded artifacts (Table 1). Table 1 lists the artifacts recovered together with their horizontal and vertical proveniences.

A total of 21 artifacts were recovered from the three shovel tests. All but one of these, a flake from ST 3 (Level 5), are of modern origin. The plastic bag and asphalt recovered at $30-40 \mathrm{~cm}$ below surface (bs) in ST 1 , and the additional modern artifacts from higher levels, are obvious indicators of recent disturbances in the eastern portion of the project area.

The single prehistoric artifact recovered during shovel testing came from ST 3, Level $5(40-50 \mathrm{~cm}$ bs). The specimen is a tertiary fine-grained quartzite medial flake fragment. The light gray to yellow mottled material was not heat-treated. Although the specimen came from $40-50 \mathrm{~cm}$ bs, it is likely that it was introduced to this depth through the numerous cracks and fissures noted in the clay loam of the immediate area. A number of nearby mounds of soil resulting from brush clearance were closely examined for evidence of other historic or prehistoric artifacts. In addition, a systematic surface inspection within a 50-meter radius of the shovel test also was conducted. This surface inspection revealed no other artifacts of note and, given the likelihood that the single flake was displaced from the surface as the area had been significantly disturbed, it was decided to continue the survey without conducting additional shovel tests in the immediate vicinity of ST 3. No additional surface or subsurface artifacts were recovered during the survey.

Table 1. Artifact Inventory and depth of shovel tests

\begin{tabular}{|c|c|c|}
\hline $\begin{array}{l}\text { Shovel Test } 1 \\
10-20 \mathrm{~cm} \text { b.s. }\end{array}$ & $\begin{array}{l}\text { Material } \\
\text { Brown Glass } \\
\text { (modern) } \\
\text { Green Glass } \\
\text { (modern) } \\
\text { Paper } \\
\text { Styrofoam } \\
\text { Plastic Toy }\end{array}$ & Amount \\
\hline $30-40 \mathrm{~cm}$ b.s. & $\begin{array}{l}\text { Asphalt } \\
\text { Plastic Bag Fragment }\end{array}$ & $\begin{array}{l}4 \\
2\end{array}$ \\
\hline$\frac{\text { Shovel Test } 3}{40-50 \mathrm{~cm} \mathrm{b.s.}}$ & Flake & 1 \\
\hline Shovel Test 5 & $\begin{array}{l}\text { Brown Glass } \\
\text { (modern) } \\
\text { Clear Glass (modern) }\end{array}$ & $\begin{array}{l}2 \\
1\end{array}$ \\
\hline
\end{tabular}




\section{Summary and Recommendations}

At the request of Ozuna and Associates, Inc., Consulting Engineers of San Antonio, Texas, in early January of 2000, personnel from CAR-UTSA conducted a pedestrian survey of a proposed 40 -acre extension to the Crystal City Municipal Landfill. The survey was carried out using 20 meter transect intervals. A total of 21 transects were traversed. In conjunction with the pedestrian survey, a total of 21 shovel tests were excavated. One prehistoric site (41ZV445), a sparse scatter $(20 \times 25 \mathrm{~m})$ of burned rock $(\mathrm{n}=5)$ and chipped lithics $(n=6)$, was identified and documented. Shovel testing revealed no subsurface cultural deposits. Given the absence of in situ hearth features, the apparent disturbed nature of the former hearths, and the low density of artifacts, the site does not appear to meet the criteria for inclusion into the National Register of Historic Places nor does it warrant State Archaeological Landmark designation. A total of three shovel tests, located in the western two-thirds of the project area, yielded subsurface cultural materials. All but one of these artifacts is of modern origin. Their presence is indicative of heavy disturbance resulting from vegetation clearance and road construction. Cultural resource clearance is recommended for the proposed landfill extension. 


\section{References Cited}

Black, S. L.

1989a South Texas Plains. In From the Gulf to the Rio Grande: Human Adaptation in Central, South and Lower Pecos Texas, by T. R. Hester, S. L. Black, D. G. Steele, B. W. Olive, A. A. Fox, K. Reinhard, and L. C. Bement, pp. 39-62. Research Series No. 33. Arkansas Archeological Survey. Fayetteville.

1989b Environmental Setting. In From the Gulf to the Rio Grande: Human Adaptation in Central, South, and Lower Pecos Texas, by T. R. Hester, S. L. Black, D. G. Steele, B. W. Olive, A. A. Fox, K. J. Reinhard, and L. C. Bement, pp. 5-16. Research Series No. 33. Arkansas Archeological Survey. Fayetteville.

1989c Central Texas Plateau Prairie. In From the Gulf to the Rio Grande: Human Adaptation in Central, South, and Lower Pecos Texas, by T. R. Hester, S. L. Black, D. G. Steele, B. W. Olive, A. A. Fox, K. J. Reinhard, and L. C. Bement, pp. 17-38. Research Series No. 33. Arkansas Archeological Survey. Fayetteville.

1995 Archaeological and Historical Background. In Archaeological Investigations at the Loma Sandia Site (41LK28): A Prehisioric Campsite in Live Oak County, Texas. Two Volumes. Studies in Archeology No. 20, pp. 31-45. Texas Archeological Research Laboratory, The University of Texas at Austin.

Black, S. L., and A. J. McGraw

1985 The Panther Springs Creek Site: Cultural Change and Continuity within the Upper Salado Creek Watershed, South-Central Texas. Archaeological Survey Report, No. 100. Center for Archaeological Research, The University of Texas at San Antonio.

Campbell, T. N., and T. J. Campbell

1981 Historic Indian Groups of the Choke Canyon Reservoir and Surrounding Area, Southern Texas. Choke Canyon Series, No. 1. Center for Archaeological Research, The University of Texas at San Antonio.

1988 The Indians of Southern Texas and Northeastern Mexico. Selected Writings of Thomas Nolan Campbell. Texas Archeological Research Laboratory, The University of Texas at Austin.

Chandler, C. K., and D. Kumpe

1994 Folsom Points from Deep South and Southwest Texas. La Tierra 21(3):6-9.

Collins, M. B.

1995 Forty Years of Archeology in Central Texas. Bulletin of the Texas Archeological Society 66:361-400.

Collins, M. B., and A. C. Kerr

1993 Archeology of the Earliest Texans. Paper presented at the 1993 Annual Meeting, Texas Archeological Society, Laredo.

Dillehay, T. D.

1974 Late Quaternary Bison Population Changes on the Southern Plains. Plains Anthropologist 19-65:180196. 
Foster, W. C.

1995 Spanish Expeditions Into Texas, 1689-1768. University of Texas Press, Austin.

Goode, G. T.

1991 Late Prehistoric Burned Rock Middens in Central Texas. In The Burned Rock Middens of Texas: An Archeological Symposium, edited by T. R. Hester, pp. 71-93. Studies in Archeology 13. Texas Archeological Research Laboratory, The University of Texas at Austin.

Hester, T. R.

1995 The Prehistory of South Texas. Bulletin of the Texas Archeological Society 66: 427-459.

Houk, B. A., and J. C. Lohse

1993[1990] Archeological Investigations at the Mingo Site, Bandera County, Texas. Bulletin of the Texas Archeological Society 61:193-247.

Huebner, J. A.

1991 Late Prehistoric Bison Populations in Central and Southern Texas. Plains Anthropologist 36(137):343358.

Largent, F. B., Jr., M. R. Waters, and D. L. Carlson

1991 The Spatiotemporal Distribution and Characteristics of Folsom Projectile Points in Texas. Plains Anthropologist 36(137):323-342.

McGraw, A. J., and J. E. Corbin

1999 A Review Essay of "Spanish Expeditions into Texas," by William C. Foster (1995). Bulletin of the Texas Archeological Society 70:439-446.

McKinney, W. W.

1981 Early Holocene Adaptations in Central and South-western Texas: The Problem of the PaleoindianArchaic Transition. Bulletin of the Texas Archeological Society 52:91-120.

Meltzer, D. J., and M. R. Bever

1995 Paleoindians of Texas: An Update on the Texas Clovis Fluted Point Survey. Bulletin of the Texas Archeological Society 66: 47-81.

Peter, D. E.

1982 Alternative Perspectives on Burned Rock Middens, In Archaeological Investigations at the San Gabriel Reservoir District, Central Texas, Vol. 2, compiled and edited by T. R. Hays, pp. 20.120.15. Archaeology Program, Institute of Applied Sciences, North Texas State University, Denton.

Prewitt, E. R.

1985[1983] From Circleville to Toyah: Comments on Central Texas Chronology. Bulletin of the Texas Archeological Society 54:201-238.

Skelton, D. W.

1977 Archeological Investigations at the Fayette Power Project, Fayette County, Texas. Research Report 60. Texas Archeological Survey, The University of Texas at Austin. 
Sollberger, J. B., and T. R. Hester

1972 The Strohacker Site: A Review of Pre-Archaic Manifestations in Texas. Plains Anthropologist 17(58):326-344.

Stevens, J. W., and D. Arriaga

1985 Soil Survey of Dimmit and Zavala Counties, Texas. United States Department of Agriculture, Soil Conservation Service.

Story, D. A.

1985 Adaptive Strategies of Archaic Cultures of the West Gulf Coastal Plain. In Prehistoric Food Production in North America, edited by R. I. Ford, pp. 19-56. Anthropological Papers No. 75. Museum of Anthropology, University of Michigan, Ann Arbor.

Turner, S. E., and T. R. Hester

1993 A Field Guide to Stone Artifacts of Texas Indians. Second Edition. Texas Monthly Field Guide Series. Gulf Publishing Company, Houston.

Vierra, B. J.

1998 4IMV120: A Stratified Late Archaic Site in Moverick County, Texas. Archaeological Survey, No. 251, Center for Archaeological Research, The University of Texas at San Antonio. Archeology Studies Program Report No. 7. Environmental Affairs Division, Texas Department of Transportation, Austin.

Weir, F. A.

1976 The Central Texas Archaic. Unpublished Ph.D. dissertation, Department of Anthropology, Washington State University, Pullman. 